\title{
ENVIRONMENTAL COSTS MANAGEMENT OF THE PROJECT: THE EXPERIENCE OF RUSSIA AND MONGOLIA
}

\author{
Igor GENGUT ${ }^{1}$, Nyamdorj DAVAAHUU ${ }^{2}$, Elena ALNYKINA ${ }^{3}$, \\ Ivan POTRAVNYY ${ }^{4}$ \\ 1,3,4 Plekhanov Russian University of Economics, Russia \\ igengut@gmail.com \\ elena-alnykina@rambler.ru \\ ecoaudit@bk.ru \\ ${ }^{2}$ Plekhanov Russian University of Economics, Mongolia \\ dabuk91@mail.ru
}

\begin{abstract}
The paper is devoted to the assessment problems of the ecological costs management of the production in the project activity. The authors study the conditions of preparation and implementation of investment projects to eliminate accumulated environmental damage in the context of "green" economy. The technogenic deposits' use approaches are considered for the purpose of the production costs optimization. The paper explains the necessity of building the fund liquidation (a fund for future generations) in the depletion of resource base of the enterprise. The proposed mechanism for the management of environmental costs in project activities can be used at the enterprises of Russia and Mongolia. For example, the Mongolian-Russian mining company "Erdenet" in Mongolia shows the direction to reduce costs and production costs through the implementation of measures for resource and energy efficiency, involving economic circulation of off-balance ores and tailings.
\end{abstract}

Keywords: Environmental economics, environmental management, mining enterprise, Mongolia, Russia.

\section{INTRODUCTION}

The previous period of economic activity (the XX century) was characterised to a greater extent by the process of industrialisation and extensive production of many kinds of natural resources. In many countries, these processes have left behind the legacy of significant environmental damage and threats to public health. Due to exhaustion and depletion of natural resources, increasing environmental costs in the exploration and production of products in the sphere of subsoil use, it is necessary to follow the principles of "green" economy.

This approach is relevant in relation to the preparation and implementation of a number of investment projects for the rehabilitation of disturbed areas as a result of economic and other activities in the past. In Russia, for example, the federal target programme "Elimination of Accumulated Environmental Damage" initiated in 2015 is to be implemented by 2026. The research object is a mining enterprise Erdenet in Mongolia, whose shareholders are Russia and Mongolia. 
The aim of the study is to optimise production costs - copper-molybdenum concentrate in the reduction of the useful component in the ore mined justified directions for the use of man-made deposits, that is, the resources of previously accumulated waste products (off-balance ore), which are formed as a result of the company in the past, for the production of roads, building materials and others.

Research problem is to analyse trends in the cost of production, environmental protection, compensation for the negative effects of economic activity on public health and others in connection with the change of ecological and economic conditions of production and the depletion of the resource base.

The result of research is the proposed mechanism for the management of environmental costs in project activities that can be used at the enterprises of Russia and Mongolia, as well as in other countries for the implementation of investment projects to eliminate accumulated environmental damage and develop the principles of "green economy" in the sphere of subsoil use.

The subject of the research is the issues of sustainable development of the company for the future, taking into account the depletion and exhaustion of its resource base and mine closure. Mongolia is currently implementing a major programme on commercialising new fields for the extraction of copper, coal and gold but some enterprises such as "Erdenet" having the copper and molybdenum remain for only 25-30 years. There is a need to find mechanisms and justifications to ensure environmentally sustainable development of territories especially in the context of cross-border nature of environmental pollution when enterprises such as "Erdenet" creating industrial waste through the water system of the river Selenge may have an impact on the ecosystem of Lake Baikal a World Natural Heritage Site. In this situation, it is particularly important to consider the formation of ecological and economic costs of production in the project activities, particularly in the mining activities under the conditions of exhaustion of their resource base.

\section{PROBLEM FORMULATION}

In the 1970s, largely due to the Club of Rome's research in economics, methods were developed for assessing the environmental issues of production costs and economic damage associated with the adverse effects on the environment and human health.

One can distinguish:

- Environmental damage inflicted as a result of violations of environmental laws. In this case, an entity is responsible for the violation of environmental laws. The enterprise uses its own fund for the consequences elimination.

- The effects of pollution and other negative consequence son the environment as a result of past economic activities. Guilty of causing harm to the environment cannot be established or cannot be prosecuted. In the second case it refers to the past, the accumulated environmental damage.

Usually it is the current damage as a result of environmental violations, environmental damage, which may arise in the future as a result of failure to take any measures to improve the environment, i.e. the prevention of environmental 
damage as a result of environmental protection measures. The accumulated ecological damage is the result of the negative environment quality changes, nature extinction due to economic activity.

With the development of scientific and technical knowledge, new requirements for the organisation of production in compliance with environmental standards, norms and rules come into sight. At the legislative level, there are tightened requirements for companies that can harm the environment. Within the framework of the implementation of the principle of "polluter pays", many countries have introduced a fee for the use of natural resources and environmental pollution. One of the priorities of many countries is their socio-economic development of the isolated transition to the principles of "green" economy. In Russia, this problem has been indicated in the Resolution of IV All-Russian Congress of the Environment (2013), which is reflected in the design of measures to involve the waste as secondary raw materials, utilisation of technogenic deposits and elimination of accumulated environmental damage, which is defined as actions aimed at recovery, rehabilitation of the environment with a view to returning to the steady state in which stability is ensured in the long term.

It should be noted that one of the global trends in the economic sphere of subsoil use is the depletion of the resource base and the exhaustion of mining enterprises. This greatly affects the basic technical and economic indicators of the data of enterprises, implies an increase in costs related to environmental factors of production and ecology.

The analysis shows that a major problem in the implementation of social and environmental projects, including investment projects in the environmental field, is to determine cost-effectiveness. Important criteria include NPV, IRR (internal rate of return), the coefficient of efficiency of investments, ARR (accounting rate of return), etc. However, there are certain areas where the generally accepted evaluation methods do not work. The implementation of environmental protection measures to obtain the maximum profit is not a priority, and in some cases the implementation of these projects may initially be expensive and unprofitable. As usually the science distinguishes:

- The primary eco-economic effect which reflects in environment pollution production.

- Comprehensive socio-economic effect which results in living-standards improving and national wealth as a whole.

It is difficult to assess in terms of money a substantial part of the social outcomes of environmental projects, such as the decrease in morbidity, improvement of conditions of work and leisure, and the like (Alnykina and Gengut, 2015). When implementing important environmental projects in the first place is not to get the maximum profit, but to achieve ecological effect of the recovery of contaminated areas. Thus, in the selection of projects it is necessary to pay attention to the following criteria:

1. The amount and composition of the accumulated dirt. When selecting environmental projects it is necessary to take into account the weight and class of hazard substances in the dirt. Objects of the most dangerous pollutants should be eliminated first. 
2. The area of territory subject to the adverse effects.

3. Location on the territory with a high degree of anthropogenic load. Using this criterion, chemical pollution of the territory can be estimated.

4. The presence of specific environmental risks. It is necessary to anticipate all the possible options in the operations envisaged by the project to eliminate the possibility of deterioration of the territory.

5. Availability of this or adjacent areas of protected areas. These areas include state nature reserves (including biosphere reserves), national parks, natural parks, state natural reserves, natural monuments, arboretums and botanical gardens.

6. Availability of technical capability for safe disposal.

For example, the efficiency assessment of the federal target program "Elimination of accumulated environmental damage" implementation on the period of 2014-2026 should be realized on the basis of the environmental and social indicators. These include the proportion of people free from the negative effects of accumulated environmental damage, \%; share of environmentally remediated and rehabilitated land involved in the economic turnover, ha; share of liquidated "hot" ecological points\%; number of developed, improved and tested technologies and biotechnologiesin the framework of the programme to eliminate accumulated environmental damage, units. Thus, a comparison with the actual targets shows how effectively the programme is implemented to determine whether the objectives of social and environmental problems are achieved.

The focus of the federal target programme addressing certain environmental and social problems is to pay due attention to the financial performance of the project. One way to increase the efficiency of the project is to reduce costs; it is necessary to develop efficient management of environmental costs in project activities. To do this, you first need to understand the algorithm of implementation of environmental projects:

7. Inventory of contaminated sites for environmental rehabilitation of the territory. Creating a registry of objects of the past environmental damage;

8. Assessment of funding needs to eliminate the past environmental damage.

9. Identifying the sources of funding for projects for environmental rehabilitation of the territory and the definition of the economic mechanism of project implementation.

10. Holding an auction for the right to work on the environmental rehabilitation of the territory.

11. Transferring the investor ownership of land and waste products;

12. Control and monitoring of the implementation of the projects.

One of the most important steps in the implementation of the project is to find bona fide artists. In order to form the market for environmental goods and services, aimed at solving the problems related to the accumulated environmental damage, in our view it is advisable to create a register of companies, enterprises, organisations that can carry out project activities. The list of information about enterprises and organisations to participate in projects for the elimination of accumulated environmental damage can include the following information: 
- name of the company;

- year of establishment, location;

- area of activity;

- number of employees;

- experience in the environmental goods and services.

Keeping this register, in our opinion, it is advisable to carry out territorial divisions of the Ministry of Natural Resources and Environment in cooperation with the regional offices of the chambers of commerce, associations of environmental business, research centres, and universities. This register should take into account the specificity of solved environmental problems at the regional level. The cost price is the main indicator among the production efficiency indexes. Getting the greatest impact at the lowest cost, saving manpower, material, natural and financial resources depend on how the company solves the issues of cost reduction, controls production costs. In the economic literature and regulatory documents, such a term as costs is often used. By costs one understands the monetary measurement of the amount of resources used with any purpose.

\section{RESULT ANALYSIS}

Socio-economic development of many countries is closely related to the use of natural resources, where GDP is largely generated by the production and export of mineral resources, such as Mongolia. Mongolia is famous for mineral resources throughout the country, such as copper mining, coal, gold and uranium. GDP is growing at a double-digit pace, rarity in today's economy. Over the next three years it will increase by 1.5 times, and this dynamics will be stable for at least another 10 years. The Mongolians companies which mine copper are LCC "Erdenet", LCC “Oyu Tolgoi”, LCC "Tsagaan Suvarga" etc.

Figure 1 shows the projected amount of copper and coal in Mongolia for the period up to 2017.
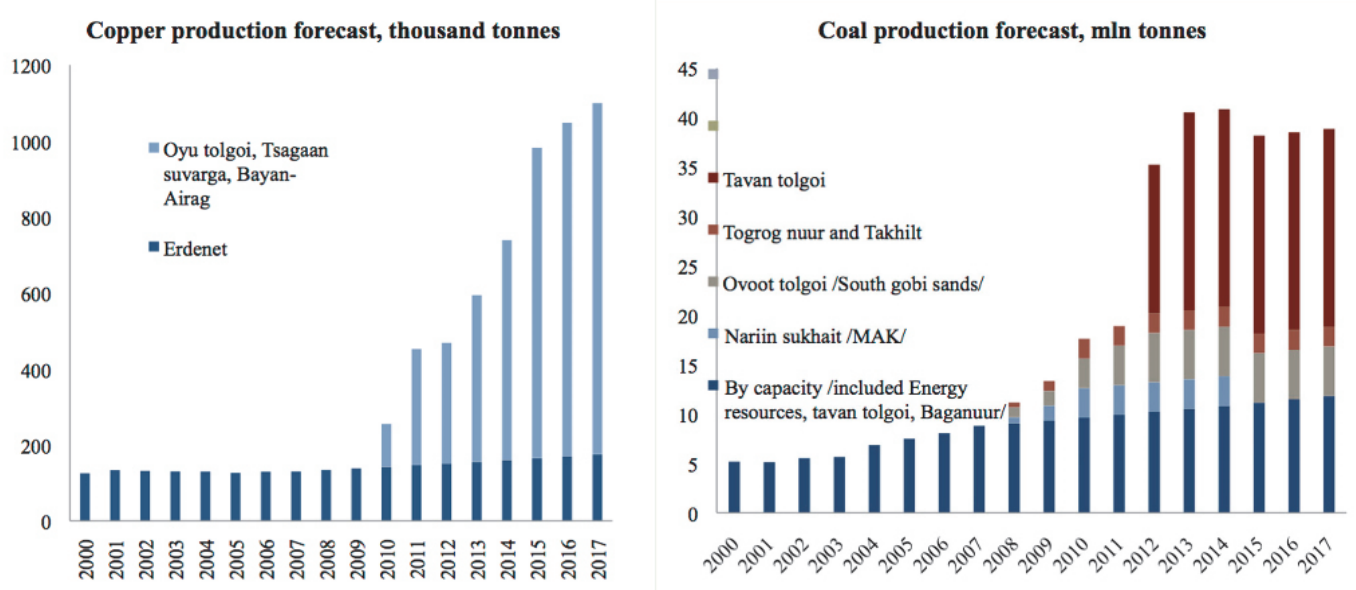

Fig. 1. Projected production of copper and coal in Mongolia (National Statistical Office of Mongolia, 2015) . 
As shown in Fig. 1, copper produced by LCC Erdenet is expected to remain stable by 2017, compared to other companies. Mongolian-Russian joint venture Erdenet, launched into operation in 1978, is the largest industrial complex in Mongolia focused on the extraction and processing of copper and molybdenum ore deposit from "Erdenetiyn-Ovoo". Geological studies show that Erdenetiyn Ovoo's deposit began to be exploited in the late 50s of the twentieth century, and the object at that time was rated as having no practical value. In 1963, geological surveys were continued at facilities. From 1964 to 1968, joint MongolCzechoslovak Geological Party carried out geological prospecting operations in the field, resulting in estimated reserves of copper-molybdenum deposit in the amount of 612 million tonnes of C2 category. Preliminary exploration of the deposit made by Mongolian scientists and technological research of coppermolybdenum ores showed that proven reserves of copper ore were at that time amounted to 670 million tonnes of $\mathrm{C} 1+\mathrm{C} 2$.

The founders of LCC Erdenet are the State Property Committee on the Mongolian side $(51 \%)$ and the state corporation Russian Technologies on the Russian side (49\%). At present, almost the entire volume of produced copper concentrate by LCC Erdenet is supplied to the Chinese market.

The analysis of production costs reveals trends in the indicators characterising the level of profitability of the enterprise to determine the influence of factors on the efficiency of its operation, as well as to identify the reserves to reduce the cost of production. On the example of the mining enterprise Erdenet, issues of governance costs of production are considered. This joint venture was established in 1974 and produces copper and molybdenum concentrate by mining and processing of copper and molybdenum ores. Table 1 shows the basic technical and economic indicators of the company for 2010-2013.

Table 1. Main Production and Economic Indicators of the Mining Enterprise Erdenet (made by the authors based on the data by LLC Erdenet, 2015)

\begin{tabular}{|l|c|c|c|c|c|c|}
\hline \multicolumn{1}{|c|}{ Indicators } & $\begin{array}{c}\text { Units of } \\
\text { measure }\end{array}$ & $\mathbf{2 0 1 0}$ & $\mathbf{2 0 1 1}$ & $\mathbf{2 0 1 2}$ & $\mathbf{2 0 1 3}$ & $\begin{array}{c}\mathbf{2 0 1 3} \text { in \%o } \\
\text { to 2010 }\end{array}$ \\
\hline Ore mass & thous. $\mathrm{m}^{3}$ & 16370 & 17150 & 17600 & 18180 & 111.1 \\
\hline Overburden & thous. $\mathrm{m}^{3}$ & 5556.3 & 5670.1 & 6313.7 & 6644.7 & 119.6 \\
\hline Ore mining & thous. t & 27575 & 29274 & 28780 & 29415 & 106.7 \\
\hline Ore processing & thous. t & 26060 & 26100 & 26030 & 26045 & 99.9 \\
\hline The content of the ore: & \multicolumn{5}{|l|}{} \\
\hline Copper & $\%$ & 0.548 & 0.540 & 0.542 & 0.530 & - \\
\hline Molybdenum & $\%$ & 0.017 & 0.017 & 0.017 & 0.017 & - \\
\hline $\begin{array}{l}\text { The price of 1 tonne of } \\
\text { cathode copper on the } \\
\text { London Metal Exchange }\end{array}$ & $\$$ & 7534.78 & 8820.99 & 7949.95 & 7326.16 & 97.23 \\
\hline $\begin{array}{l}\text { Cost of ore processing } \\
\text { per tonne }\end{array}$ & $\$ / \mathrm{t}$ & 7.01 & 8.55 & 9.24 & 8.47 & 120.8 \\
\hline $\begin{array}{l}\text { Release of dry copper } \\
\text { concentrate }\end{array}$ & t. & 522033 & 503366 & 517782 & 512854 & 98.24 \\
\hline $\begin{array}{l}\text { Average number } \\
\text { of employees }\end{array}$ & pers. & 5762 & 5787 & 5767 & 5797 & 100.6 \\
\hline
\end{tabular}


As can be seen from Table 1, on the one hand, there is a tendency to reduce the mineral content (copper) in the mined ore, which suggests maintaining the output of finished products, involving a larger volume of the rock mass, overburden in mining ore, as well as the rising cost of its processing. This trend increases volume indicators, i.e. mining and ore processing, production, metal recovery, while reducing the copper content in ore.

Processing costs of 1 tonne of ore and 1 tonne of copper concentrate increase every year, mainly due to rising prices for normalized materials, energy, services, processing and service departments, outside organisations, depreciation due to water of new equipment, as well as wages. Thus, if the production of rock mass increased by 1810 thousand $\mathrm{m}^{3}$ in 2013 compared to 2010, ore processing remained at the same level, the output of copper and molybdenum dropped significantly. At the same time, the content of copper and molybdenum in ore also decreased by $0.018 \%$ and $0.028 \%$, respectively.

Analysis of the cost of commercial products indicates that its release for the period under review also declined. It is estimated that in the foreseeable future (25-30 years) due to the depletion of mineral reserves and mine closure the impact of resource and environmental factors will increasingly be felt in the main production and environmental performance. This has already been reflected in the determination of the production costs (Potravny \& Alnykina, 2015). It is necessary to keep in mind not only the direct costs, but also those that are formed on the basis of fees for the use of natural resources, as well as the fees aimed to neutralise and reduce the negative impact on the environment (payment for environmental pollution, compensation for environmental damage, and others) (Potravny \& Nyamdorj, 2015).

It should be noted that in 2011 the price of copper reached the highest level compared to all previous years; it had a positive impact on sales of marketable products and a profitable part of the company. This factor greatly promoted the implementation of measures, involving economic circulation of off-balance ores and tailings that at the same price for copper was insufficiently profitable. This approach allows profitably involving economic turnover of balance ores and resources of the so-called "man-made" fields (Alnykina \& Gengut, 2015; Potravny \& Nyamdorzh, 2015). During the reporting period, there was a significant change in the structure of production costs of the enterprise in the direction of increasing the proportion of nature and resource factors. It should be noted that the indicators of the cost of mining and ore processing, as well as the overall costs of production of marketable products have begun to decline since 2011, due to the measures taken to reduce costs and implement measures for the development of resources.

Table 2 shows the structure and dynamics of changes in production by LCC Erdenet for 2010-2013, \%. Thus, in 2013, the share of natural resource payments in the structure of production costs by the company (board of mineral resources, for land, for water use) amounted to $30.4 \%$ and increased by $22.2 \%$ in comparison with 2010. Comparison of actual data with the planned indicators shows that in 2010-2011 the production costs of the enterprise decreased by $6.4 \%$ and $7.4 \%$, respectively, and in 2012 there was the growth of the actual cost by $1.1 \%$. 
During the period from 2010 to 2012, an average annual growth rate of actual total production costs of 1 tonne of dry copper concentrate was $4.6 \%$; the planned growth was provided at a rate of $5.4 \%$.

Table 2. The Structure of the Production Costs of the Mining Enterprise Erdenet, $\%$ (made by the authors based on the data by LLC Erdenet, 2015)

\begin{tabular}{|l|l|c|c|c|}
\hline \multicolumn{1}{|c|}{ No. } & \multicolumn{1}{|c|}{ Cost elements } & $\mathbf{2 0 1 0}$ & $\mathbf{2 0 1 4}$ & $\begin{array}{c}\text { Change } \\
\text { deviation (+,-) }\end{array}$ \\
\hline & The cost of production of marketable products & 100.0 & 100.0 & - \\
\hline 1. & Supporting materials & 18.5 & 20.1 & +1.6 \\
\hline 2. & Fuel from the side & 0.5 & 1.1 & +0.6 \\
\hline 3. & Energy from the side & 6.2 & 10.0 & +3.8 \\
\hline 4. & Salary (basic and additional) & 8.1 & 15.9 & 7.8 \\
\hline 5. & Allocations for social and health insurance & 1.1 & 2.1 & +1.0 \\
\hline 6. & Amortisation of fixed assets & 6.6 & 10.4 & +3.8 \\
\hline 7. & Non-production costs & 2.8 & 3.9 & +2.1 \\
\hline 8. & Other cash expenses, including: & 60.3 & 37.1 & -23.2 \\
\hline & $\begin{array}{l}\text { additional tax on the increase in prices of } \\
\text { finished goods (68 \%) }\end{array}$ & 47.2 & - & -47.2 \\
\hline & fee for subsoil & 7.0 & 28.0 & +21.0 \\
\hline & payment for land & 1.0 & 1.1 & +0.1 \\
\hline & payment for use of water & 0.2 & 1.3 & +1.1 \\
\hline & property tax & 4.8 & 5.6 & +0.3 \\
\hline & Other & 0.5 & +0.8 \\
\hline
\end{tabular}

By analysing the structure of the actual cost of production, it should also be noted that the reporting period was characterised by an increase in the share of material costs, which was a consequence of productivity growth (an average of $0.14 \%$ per year) and by a decrease in volume of work, as evidenced by the decline in the share of salary expenditures.

At present, LLC Erdenet produces 530.0 thousand tonnes of copper and more than 4.0 thousand tonnes of molybdenum concentrate. Consequently, the performance of mining ore pit of the central portion was 8.0 million tonnes/year (see Table 3).

Table 3. Performance for the Extraction of Ore at the Mining Enterprise Erdenet, 2014 (made by the authors based on the data by LLC Erdenet, 2015)

\begin{tabular}{|c|c|c|c|}
\hline \multirow{2}{*}{$\begin{array}{c}\text { Copper content in } \\
\text { ore, \% }\end{array}$} & \multicolumn{3}{|c|}{ Performance of ore quarries, mln. T / year } \\
\cline { 2 - 4 } & Northwest section & Central section & Total \\
\hline 0.25 & 30.0 & 5.0 & 35.0 \\
\hline 0.15 & 29.0 & 6.0 & 35.0 \\
\hline
\end{tabular}


The total area of disturbed land due to mining will be 290.9 hectares; the total losses amount to $4618.3 \mathrm{t}$ of humus. Environmental damage to the soil will then reach 42 thousand $\$$.

\section{CONCLUSION}

The analysis of the enterprise cost elements shows that the bulk of expenditure $\mathrm{s}$ is attributed to material costs, labour costs, and other expenses and, therefore, these elements should be given special attention in the identification of reserves to reduce costs. Reserves to reduce the costs can be as follows: a decrease in the cost of raw materials as a result of the replacement of some kinds of raw materials, fuel, other.

In the course of assessing the dynamics of building blocks of production costs of 1 tonne of dry copper concentrate for the period under review, it has been revealed that among the analysed components of the structure of production costs, material costs have the greatest impact on the overall magnitude of cost per 1 ruble of production. An analysis of the indicators characterising the efficiency of production has revealed that one of the leading indicators is the cost of production, as it reflects many aspects of production and financial activities of the organisation.

The comprehensive analysis of the production costs of LCC Erdenet has been performed for the costs reducing opportunities identification. The reserves could include technogenic deposits and off-balance ore and tailings. They help to prolong the enterprise functioning and to increase the eco-economic costs.

As shown in the study performed by the environmental-economic analysis, one of the negative trends in the activities of the mining company for the future is the exhaustion of the deposit, which is manifested in a decrease in the content of useful component in ore mined and increased costs of processing and finished products. It should be noted that in a globalised economy, there is close relationship between such concepts as profit, cost, etc.

\section{ACKNOWLEDGMENT}

The present research has been supported by the Russian Humanitarian Foundation, project No. 15-02-00141a, project No. 15-22-00303

\section{REFERENCES}

Alnykina, E. M. Gengut, I. B. (2015). Models and methods of strategy development companies to eliminate environmental violations. Strategic Planning and Business Development. Materials XVI All-Russian symposium. Section 2, Moscow: CEMI, pp. 10-12.

Erdenet Mining Corporation. (2015). Retrieved from http://www.erdenetmc.mn.

Fomenko, A. (2013). The use of man-made accumulations and off-balance ores of non-ferrous metals in the context of environmental Economics. Mining journal, 2, 93-95.

Gassiy, V., Gengut, I. (2015). Innovative Approaches to Formation of Industrial Clusters in the Mining Industry. ICIED 2015: The International Conference on Innovation and Entrepreneurship Development. Ulaanbaatar: Mongolian University of Science and Technology, Mongolia, pp. 16-18. 
Namnyambuu, B. (2014). Analysis of trends in the environmental component of production costs mining enterprise in the conditions of exhaustion of the resource base. System analysis and modelling of economic and ecological systems. Ecology. Economy. Computer science. Sat. articles of the all-Russian Conf. Rostov-on-don: Publishing house of the southern Federal University, 1, 274-279.

National Statistical Office of Mongolia. (2015). Retrieved from www: //nso.mn/

Narankhuu, H., Enkhtuya, P. (2007). Development Strategy SP "Erdenet" for the period until 2015. Mining journal, 9, 9-11.

Nyamdorj, D. (2015). Ecological and Economic SWOT-analysis of the mining enterprise "Erdenet". Theory and practice of economic regulation of natural resources and environmental protection. Proceedings of XIII International scientific-practical conference of the Russian Society for Ecological Economics (pp. 238-243). Moscow.

Maam, X. (2009). Innovation: The Way to the development of Mongolia. Innovations: Mongol ulsyn hogzhiliyn Harz, Ulaanbaatar. pp. 20-22.

Potravny, I. M., Alnykina, E. M. (2015). On the question of performance criteria in the evaluation of investment projects in the environmental field. Modern problems of project management in the field of investment and construction and environmental management. Proceedings of V International scientific and practical conference (pp. 218-223). Moscow: Grief and K.

Potravny, I. M. \& Nyamdorj, D. (2015). Economic evaluation of accumulated environmental damage at the closing of the mine ore mining and processing enterprise. Ecology. The Economy. Computer science. Coll. articles "System analysis and modelling of economic and ecological systems." Rostov-on-Don: Publishing Junior Federal University, 2, 505-510.

Potravny, I., Motosova, E. (2014). Economic mechanism for implementation of ecological policy in subsoil use. Mining journal, 12, pp. 27-30.

Research Tools in Natural Resource and Environmental Economics (2011). Ed. by Amitrajeet A. Batabyal and Peter Nijkamp. London: World Scientific Publishing. p. 400. http://dx.doi.org/10.1142/7496

Resolution IV all-Russian Congress on environmental protection. (2013). Retrieved from http://www.mnr.gov.ru/regulatory/detail.php?ID=131936\&spetial=Y/

Russian Federation Government (2014). Retrieved from http://government.ru/media/files/iOdZdo6HLmc.pdf

The Economics and Politics of Climate Change (2011). Ed. by Dieter Helm and Cameron Hepburn. New York: Oxford Review of Economics Policy. p. 538.

Vega, A., Fomenko, A., Potravny, I. (2012). The efficient use of resources as a factor of increasing environmental and energy efficiency of the economy and ensuring social standards of living of the population. Plekhanovsky research Bulletin, 1(1), 45-60.

\section{AUTHORS' SHORT BIOGRAPHY}

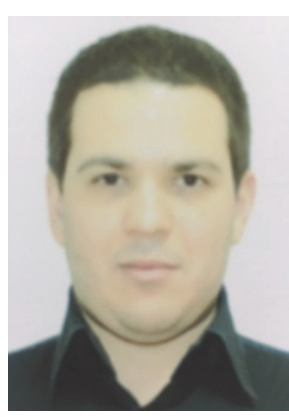

Igor Gengut, $\mathrm{PhD}$, Doctoral student at the Department of Management of Projects and Programmes, Plekhanov Russian University of Economics. Research interests include environmental economics, environmental business, elimination of accumulated environmental damage, environmental support project activities. He is a member of the research projects within the framework of the Russian Humanitarian Foundation, including RussianMongolian research projects on the elimination of accumulated environmental damage and resources, involving man-made deposits into economic circulation.

Author's contact data:

Phone: +7 9171125550 


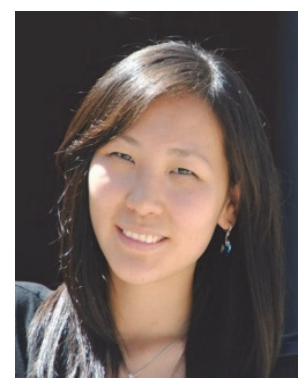

Davaahuu Nyamdorj is a citizen of Mongolia, a graduate student of the Department of Management of Projects and Programmes, Plekhanov Russian University of Economics. Research interests include environmental economics, cost management, environmental economics. She is the author of publications on environmental economics.
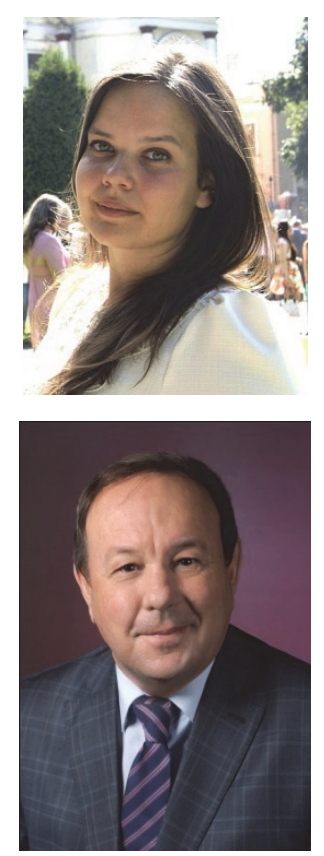

Potravny Ivan, Doctor of Economics, Professor, Plekhanov Russian University of Economics. He is the author of over 350 scientific articles, monographs, textbooks in the field of environmental economics, sustainable development, mechanism of management of ecological-economic projects. He has participated in international projects and conferences in the field of "green" economy, environmental management in Germany, Switzerland, Latvia, Mongolia, China, Vietnam, Thailand, Ukraine, the Czech Republic etc. He has prepared 62 candidates and doctors of economic sciences in the field of environmental economics and regional economics. He is a member of the European and the Russian Society for Ecological Economics, Free Economic Society of Russia, member of the Expert Council under the government of the Russian Federation. 